\title{
A 2009. ÉVI PÉNZÜGYI ÉS GAZDASÁGI VÁLSÁG HATÁSA AZ ÉLELMISZER-KISKERESKEDELEMRE A FOGYASZTÓI BIZALOM TÜKRÉBEN - JAVULÓ TRENDEK, ÉBREDEZÓ FOGYASZTÓI BIZALOM
}

\author{
- no
IMPACT OF THE FINANCIAL AND ECONOMIC CRISIS OF 2009 ON THE HUNGARIAN FOOD RETAIL SECTOR IN THE LIGHT OF CONSUMER CONFIDENCE - IMPROVING TRENDS, INCREASING CONSUMER CONFIDENCE \\ - \\ KRISTÓF, Erzsébet \\ HARANGI-RÁKOS, Mónika \\ $-10$ \\ Debreceni Egyetem, Gazdaságtudományi Kar, Ágazati Gazdaságtan és Módszertani Intézet \\ (University of Debrecen, Faculty of Economics and Business, Institute of Sectoral Economics and Methodology) \\ H-4032 Debrecen, Böszörményi út 138 . \\ e-mail: erzsebetkristof@gmail.com
}

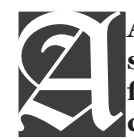

As a result of the international financial and economic crisis of 2009, Hungarian customers started to make informed purchasing decisions. Merchants recognizing this phenomenon formed their strategies accordingly, while trying to meet the requirements of the constantly changing government regulations. This strategy ensured primarily that they could maintain their position in trading, new consumer expansion was, however, limited. Limited because consumers have realized the situation, i.e. traders have been competing for their income and complex shop visiting has become widely common, implying the weekly tour of different shops in retail chains with an eye on the current promotions. Based on the data of the last eight years, the year most affected by the economic crisis was 2009 - which proved to be the deepest point. It has to be highlighted however that though signs of recovery are clearly visible, the volume of food retail returned to its growth path only in 2014, while sale increase in value has been continuous since 2008. This suggests that the impulses of the crisis starting in the fourth quarter of 2008 formed the domestic food trade for full six years. Also, this period was required to regenerate consumer trust. The more favourable prospects of the finances of both individuals and the economy encourage an increase of willingness to buy. The six-year period impacted by the crisis intensified concentration among trade stakeholders. The forecasts proved realistic, supermarkets have become more popular sites for shopping, although hypermarkets as strong competitors have been able to keep pace due to tailored promotions in the 6 trading days permitted by law until April 2016. Due to the massive social and political pressure the Government repealed the Act prohibiting work on Sundays in most retail shops with effect from 16 April 2016.

KuLCSSZAVAK: válság, élelmiszer-kereskedelem, fogyasztói bizalom index, fogyasztói magatartás
KEYWORDS: crisis, food trade, consumer confidence index, consumer behaviour

JELKóD: M30 General 


\section{BEVEZETÉS - INTRODUCTION}

A pénzügyi és gazdasági válság 2008 októberében Magyarországot is elérte. Valamennyi ágazathoz hasonlóan az ez irányú változások hatásai az élelmiszer-kereskedelemben is megmutatkoztak. A válság fogalma PEARSON és CLAIR (1998) szerint olyan rendellenes esemény, amely katasztrofális hatással lehet a cégre, akár teljesen szét is rombolhatja.

A vásárlókat érintő prognosztizált hatások között számos olyan szerepel, mely nem kizárólagossággal következett be (például automatikus átállás a „B” típusú brandekre), illetve több esetben nem is bocsátkoztak trendek prognosztizálásába, hiszen az elmúlt nyolc év távlata újraírta a meglévő előrejelzéseket. Kijelenthető azonban, hogy a gazdasági válság vásárlóerő-csökkenést indukált, mely komolyan kihatott a kiskereskedelem minden szereplőjére (JANKUNÉ, STAUDER és GYÖRE, 2012). A fenti megállapítást igazolja RAMPELL (2009): recesszióban egyrészt csökken a fogyasztók vásárlóereje, másrészt pedig bizonytalanok abban, hogy mikor várható újra fellendülés. Emiatt takarékossá válnak és elhalasztják a termékek vásárlását vagy a szolgáltatások igénybevételét, vagy eleve kerülik a vásárlási helyzeteket.

Jelen munkánk célja, hogy bemutassuk a fóbb mérföldköveket a válság kezdeti időszakától egészen napjainkig, figyelembe véve az élelmiszerfogyasztói és -kereskedői oldalt érintő tendenciákat, eseményeket Magyarországon. További célunk ugyanakkor választ találni arra vonatkozóan, hogy kilábalt-e az élelmiszer-kiskereskedelem a válságból. A fentiek ismereté- ben a cikk a 2008 óta húzódó gazdasági válság élelmiszer-kereskedelemben megnyilvánuló hatásaira reflektál.

E célok megvalósítását egyrészt a hazai és nemzetközi szakirodalmak számbavételével kívánjuk elérni, másrészt a folyamat előrehaladtának hatásait bemutató nemzetközi jelenléttel rendelkező piackutató intézetek publikációinak elemzése alapján és a Központi Statisztikai Hivatal kapcsolódó adatainak felhasználásával.

\section{A FOlYAMAT MÉRFöldKöveI - Milestones of the Process}

Az első kutatások a 2008-as recesszióval kapcsolatban 2009 januárjában jelentek meg. A GfK Hungária Piackutató Intézet és a Corvinus Egyetem 2004 tavasza óta (2015. II. negyedévvel bezárólag) közösen készíti el minden negyedévben a Komplex Fogyasztói Bizalom Index (FBI) felmérést. A felmérés célja annak kiderítése, hogy miként változnak a fogyasztói attitűdök és várakozások, illetve hogyan befolyásolják ezek a változások a fogyasztók vásárlási és megtakarítási döntéseit. A mutatószám 5 elemből tevődik össze, melyek:

- a háztartások tartós fogyasztási cikkek iránti vásárlási hajlandóságának mértéke,

- jelenlegi anyagi helyzetüknek az egy évvel korábbihoz viszonyított megítélése,

- jövő évi pénzügyi helyzetükre vonatkozó várakozásaik,

- valamint az ország következő 12 hónapban és az elkövetkező 5 évben várható gazdasági helyzetének megítélése. A fentiek rendszerét szemlélteti az 1. ábra. 
Kérdések (Questions)
Részindexek (Subindices)
Főindex (Main index)

1. Vásárlási hajlandóság tartós fogyasztási cikkek iránt (1. Willingness to buy durable goods)

2. Háztartások jelenlegi pénzügyi-anyagi helyzete az előző évhez viszonyítva (2. Current financial-fiscal situation of households compared to the previous year)

3. Háztartások jövő évi pénzügyi-anyagi helyzetre vonatkozó várakozásai (3.

Expectations of households for the next year concerning finances and assets)

4. Az ország várható gazdasági helyzete a következő 12 hónapban (4. Expected economic situation of the country in the next 12 months)

5. Az ország várható gazdasági helyzete 5 év múlva (5. Expected economic situation of the country in 5 years)
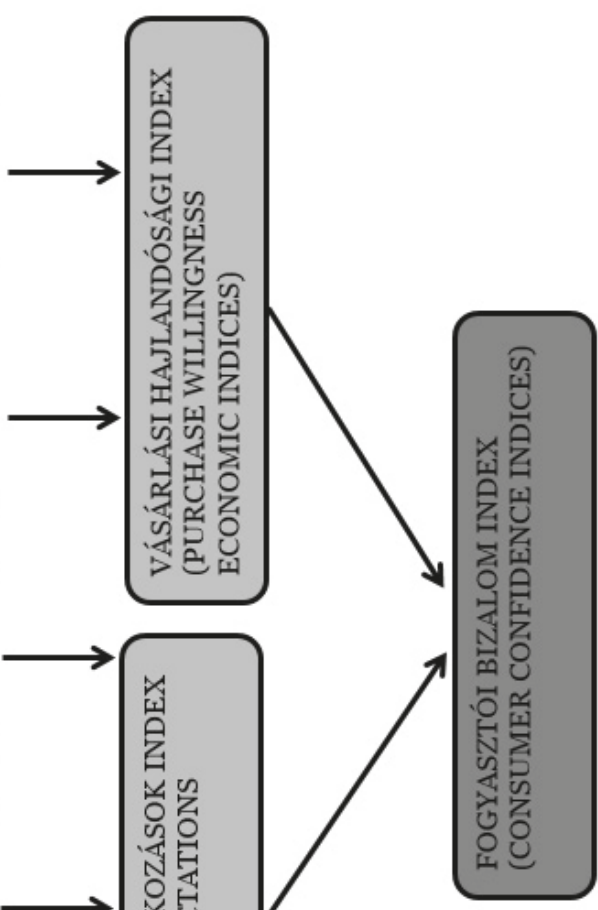

\section{1. ÁBRA}

Az indexek komponensei

Forrás (Source): GfK, 2013.

\section{(The Components of the Indices)}

FIG. 1 
A Corvinus Egyetem és a GfK Hungária Piackutató Intézet közös kutatási eredményében foglaltak szerint a 2008 decemberében mért komplex Fogyasztói Bizalom Index (FBI) értéke 2008 szeptemberéhez viszonyítva 26\%os csökkenést mutat 124,4 pontos értékével (2. ábra). Nem a fenti érték jelenti azonban a legnagyobb visszaesést, mivel az index 2006 második negyedévében 52\%-kal csökkent (GfK, 2008). 2008 negyedik negyedévében volt tapasztalható jelentősebb visszaesés FBI és Vásárlási Hajlandósági Index (VHI) tekintetében egyaránt.

$\mathrm{Az}$ FBI további értékeit figyelembe véve 2009 első negyedévében volt tapasztalható jelentősebb mértékủ index visszaesés, nevezetesen 114,5 ponton állt, ami a 2008. évi átlag 141,1 pontos értéktól 26,6 ponttal tér el. 2009 első negyedéves csökkenését követően növekedés vehető észre a hátralévő három negyedévben 146-148 pont közötti értékekkel 2009 első negyedévéhez viszonyítva.

A VHI értékei az FBI-hez hasonlóan 2009 első negyedévében estek vissza jelentős mértékben 102 pontra, 2008 negyedik negyedévéhez képest 15,6 ponttal.

A Fogyasztói Várakozások Indexe (FVI) 126 pont értékével 4,5 pontos csökkenést mutat 2008 utolsó negyedévéhez képest, így ez a mutató redukálódott legkevésbé (2. ábra).

A 2. ábrán szereplő adatok alapján a 2009es év tekinthető a válság mélypontjának, melyhez emelkedő, azonban mégsem kimagasló vásárlói hajlandóság társul. A komplex Fogyasztói Bizalom Index átlagos értéke a 2009. évben 138,9 pontot mutat. A VHI 110,2 pontnak megfelelő értéke az eddigi legalacsonyabb értéknek bizonyult. Az FVI 160,8 pontos értéke nem számít kiugró értéknek 2008-hoz viszonyítva.

A vásárlási hajlandóságra hatást gyakorolt a 2009-ben életbe lépő általános forgalmi adó normál kulcsának 20\%-ról 25\%-ra történő emelése, míg ezzel 20\%-ról 18\%-ra mérséklődött egyes alapvető élelmiszerek (tej, tejtermék, kenyér, péksütemény) ÁFA-ja (KSH, 2011a).

A BCE-GfK 2010. évi komplex FBI kutatásában az FBI értéke jelentős javulást mutat 2008-hoz képest átlagosan 26,85 pontos emelkedésével. A VHI ebben az évben sem módo- sult jelentősen átlag 120 pont értékével, míg az FVI minden eddigi értéket felülmúlva 210 pont fölé emelkedett. Ehhez kapcsolódva a Központi Statisztikai Hivatal 2008-2010 közötti jelentése a kiskereskedelemról arról számol be, hogy a kiskereskedelmi forgalom növekedését még 2010-ben is gátolta a lakossági vásárlóerő gyengesége ( $\mathrm{KSH}, 2 \mathrm{2011b})$.

A 2011-es év egyik legnagyobb változását generálta a szeptemberi élelmiszer-kereskedelemben bevezetett népegészségügyi termékadó az energiaitalok, édesipari termékek, levesporok és üdítőitalok körében. A válság következtében már egyébként is megtorpant vásárlőerő újabb csökkenést okozott az adóval érintett termékek forgalmában. Az új adónem terheit ugyan csak részben hárították a felsorolt termékkategóriák gyártói a vásárlókra, de ezzel együtt is csökkenés történt forgalmukban. Az FBI értékének átlaga 135,6 pont volt a 2011es évben, mely mindössze 6 ponttal marad el a 2008. évi átlagtól. A VHI átlagos értéke 17 ponttal kevesebb, mint 2008-ban, ugyanakkor a saját és a gazdaság helyzetének megítélését kifejező FVI-t a 2011-es év eleji állapothoz képest 51 pontos csökkenés jellemzi.

2012-ben az FBI értéke továbbra sem érte el a válság előtti szintet, 13 ponttal maradt el átlag 128 pontos értékével. A VHI 107,5 pontos átlagértéke minden eddig tapasztaltnál alacsonyabb, mely megállapítás az FVI értékére is érvényesnek tekinthető.

A 2013-as év értékei arra engednek következtetni, hogy pozitív kilátások övezik a társadalmat mind a fogyasztók saját, mind pedig a gazdaság helyzetére vonatkozóan, ennek eredményeként az FBI értéke is pozitív képet mutat. 2008-hoz képest ugyan 23,1 pontos javulást vehető észre az FBI értékében, mely azonban mégsem éri el a 2010. évi 168 pontos értéket. VHI tekintetében az eddigi évek legmagasabb értéke volt tapasztalható 128,6 ponttal, ez az érték mindössze 2,75 ponttal marad el a 2008 évi átlagtól. Az FVI 196,1 pontos értéke ad magyarázatot a fenti két mutató stabilizálódására, mivel ez az érték minden eddigit meghalad. Visszatért a fogyasztók vásárlási kedve, mely azonban racionálisabb költési struktúrát mutat.

A BCE-GfK ez irányú kutatásának 2014. évi eredményei szerint az indexek újabb bizako- 
dásra adnak okot, mivel a Fogyasztói Bizalom Index átlag 169,8 pontos értéke a korábbi évek értékei közül a legmagasabbnak bizonyult. Ugyanez elmondható a VHI-ról 141,8 pontos értékével. Az FVI esetében nem állapítható meg „rekord” érték (195,1 pont), de ez is elegendő volt ahhoz, hogy a fenti két index oly mértékű emelkedést érjen el, ami a recesszió végének tekinthetô az FBI szerint.

2015 második negyedévéről áll rendelkezésre az utolsó Corvinus Egyetem és a GfK Hungária Piackutató Intézet által készített kutatás a komplex Fogyasztó Bizalom Indexre vo- natkozóan. Ezen két negyedév adatai az alábbi következtetéseket teszik lehetővé. Az FBI értéke átlag 166,1 pont, melyet 149 pontos VHI kísér a 181,6 pontos FVI mellett. Valamennyi index meghaladja a válság előtti kettő negyedév értékeit, így az FBI esetében 21,15 pontos növekedés tapasztalható a 2008. I-II. negyedéves átlag értékéhez képest. Ugyanezen időszak Vásárlási Hajlandóság Indexe 17,4 pontos növekedést mutat, míg az FVI értéke átlagosan 24,6 ponttal emelkedett 2008. I-II. negyedévéhez képest.



2. ÁBRA

Az indexek értékeinek alakulása 2008-2015 között

FIG. 2 Forrás (Source): GfK, 2008-2015. 


\section{3. „NYERTESEK” ÉS „VESZTESEK” - „WINNERS” AND „LOOSERS”}

A vásárlói oldalon megnyilvánuló hátrányos tendenciák, így például a csökkenő kosárérték, üzletlátogatási szám, reáljövedelem jelentős változást eredményeztek a kereskedelmi üzletek számában és annak összetételében is (1. táblázat).

Folyamatos alkalmazkodás szükséges a fó fogyasztói típusokhoz (takarékoskodók, értékkeresők, gondtalan vásárlók) és a közöttük fennálló arányok változásaihoz (TINER, 2013).

A vásárlók differenciálódásával együtt a kereskedelmi források is differenciálódtak, egyre jellemzőbb bolttípus a szakbolt, a specializálódott kínálat igénylése és a nagy hálózatokban való széles kínálat igénybe vétele. Egyre nagyobb szerephez jutnak a diszkontáruházak és a boltok is, ahol árelőnyre lehet szert tenni és a rutinvásárlásokat is hatékonyabban el lehet végezni. A differenciálódási folyamat a kereskedelem igen jelentős mértékű koncentrációjával jár együtt (TÖRŐCSIK, 2007).

Nagy változás ment végbe a keresleti oldalon, a fogyasztói környezetben is, pontosabban magában a vásárlóban, a vásárlások értelmezésében, bonyolításában egyaránt. Ma a fogyasztó számára természetes, hogy válogathat a különféle típusú márkák, üzletek között, ami egyrészt szórakoztatja, másrészt egyre több, újabb termékkel, üzleti formával, üzlethálózattal kell megismerkednie, ami fárasztó, frusztráló számukra. Ismert egy úgynevezett fogyasztó történelmére vonatkozó csoportosítás, melyben megkülönböztethető a kiszámítható fogyasztó, a kiszámíthatatlan fogyasztó, a válságtanult fogyasztó és megokosodott fogyasztó csoportja. A válságtanult fogyasztó esetében a tudatos vásárlás már nem kívánalom lesz, hanem a túlélés eszköze. A családoknak nagy számban szükséges megfontolniuk eddigi kiadási szerkezetüket, döntési szempontjaikat. Napjainkban újabb korszak mutatkozik, a megokosodott fogyasztó karakterével, akiknél jelentős mértékben az anyagiasság, az ellenszolgáltatásokat elváró magatartás dominál.
Ha vásárol, akkor egyfajta „szívességet” tesz a kereskedőnek, termelőnek, ezért jutalom jár neki, melyet árengedmények, egyéb kedvezmények, nyeremények formájában vár el. Miután a válság alatt kénytelen volt megtalálni a legkedvezőbb forrásokat, ezért most is megtartva szokását, az interneten keresztül informálódik, rendszeresen keresi a legjobb ár-érték arányú megoldásokat (REKETTYE, TÖRŐCSIK és HETESI, 2015).

Az alábbiakban a meghatározó kereskedelmi szereplők 2008-2014 intervallumra vonatkozó üzletnyitási és közölt forgalmi adatainak ismertetése történik az eközben érvényesülő trendek bemutatásával.

A TESCO esetében prominens üzletszám-növekedés állapítható meg nyolc év adatait tekintve. Forgalma 2014-ben 715 milliárd forintot ért el, melytől magasan elmaradnak a mögötte szereplő láncok (2. táblázat). 2014-ben 209 nagy alapterületü üzletével és széles szortimentjével szolgálja ki vásárlóit. Az ACNilesen által készített toplista élén áll 2008 óta, melyet az elmúlt évek szabályozásai 2015-ben 13 üzletének bezárásával érintettek (TRADEMAGAZIN.HU, 2009-2015).

A CO-OP hálózat üzletszámában szerepet játszik a 2008. évi Plus lánc üzleteinek átvétele, illetve a CO-OP Szolnok Zrt. akvizíciója a Héliker Zrt. üzleteire vonatkozóan. A lánc 560 milliárd forintnyi forgalmával, melyet 5370 bolttal ért el a 2. legjelentősebb lánc a TESCO GLOBAL Áruházak Zrt. mögött. A magyar érdekeltségü láncok közül 2013-ban váltotta a CBA-t piacvezető helyén.

Az ACNielsen Piackutató által 2009-ben ismertetett Shopper Trends kutatási eredményei szerint a vásárlók nem kizárólagosan az alacsony árak alapján választanak vásárlási helyszínt, hatékonyan, lehetőség szerint a vásárlási listájukon szereplő valamennyi terméket egy helyen kívánnak megvásárolni. A kutatás szerint a hazai érdekeltséggel rendelkező láncok fő erőssége a jó kiszolgálást nyújtó személyzet, a kényelmes megközelíthetőség, a sajátmárkás termékek választéka, a gyors pénztárak és a termékek megfelelő kihelyezése (TÓTH, 2010). 
A 2009. ÉVI PÉNZÜGYI ÉS GAZDASÁGI VÁLSÁG HATÁSA AZ ÉLELMISZER-KISKERESKEDELEMRE A FOGYASZTÓI BIZALOM TÜKRÉBEN JAVULÓ TRENDEK, ÉBREDEZÓ FOGYASZTÓI BIZALOM

1. TÁBLÁZAT

TABLE 1

FMCG üzletek számának alakulása 2008-2014 között

(The Number of FMCG Stores between 2008-2014)

\begin{tabular}{|c|c|c|c|c|c|c|c|}
\hline Üzlet neve (Name of Shop) & 2008 & 2009 & 2010 & 2011 & 2012 & 2013 & 2014 \\
\hline Aldi & 45 & 58 & 73 & 78 & 86 & 93 & 100 \\
\hline Auchan & 11 & 12 & 12 & 12 & 19 & 19 & 19 \\
\hline CBA & 3038 & 3054 & 3072 & 3077 & 3225 & 2538 & 2289 \\
\hline $\mathrm{CO}-\mathrm{OP}$ & 5250 & 5250 & 5250 & 5225 & 5459 & 5480 & 5370 \\
\hline Cora & 7 & 7 & 7 & 7 & & - & \\
\hline Csemege Match & 124 & 122 & 123 & 121 & 63 & & 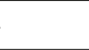 \\
\hline Héliker & 53 & & & & & & \\
\hline Metro & 13 & 13 & 13 & 13 & 13 & 13 & 13 \\
\hline Lidl & 105 & 122 & 135 & 148 & 156 & 159 & 163 \\
\hline Penny Market & 169 & 178 & 186 & 189 & 191 & 193 & 197 \\
\hline Profi & 73 & 73 & 73 & & 73 & & . \\
\hline Plus & 172 & & & & & & \\
\hline Reál & 2310 & 2320 & 2320 & 2140 & 2300 & 2314 & 2300 \\
\hline Spar & 391 & 398 & 399 & 389 & 391 & 401 & 419 \\
\hline TESCO & 148 & 176 & 205 & 212 & 216 & 220 & 209 \\
\hline
\end{tabular}

Forrás (Source): TRADEMAGAZIN, 2009-2015

2. TÁBLÁZAT

Kereskedelmi toplista 2008-2014

(Trade High Score 20o8-2014)

\begin{tabular}{|c|c|c|c|c|c|c|c|}
\hline \multirow{2}{*}{ Üzlet neve (Name of Shop) } & \multicolumn{7}{|c|}{$\begin{array}{l}\text { Összes bruttó forgalom (Milliárd forint) } \\
\text { (Total Gross Turnover in billion HUF) }\end{array}$} \\
\hline & 2008 & 2009 & 2010 & 2011 & 2012 & 2013 & 2014 \\
\hline Aldi & $20,1^{*}$ & $49,1^{*}$ & $52,6^{*}$ & $69^{*}$ & $85^{*}$ & $97,8^{*}$ & $112,1^{*}$ \\
\hline Auchan & 221,7 & 226,3 & 224,8 & 230 & 258 & 275,7 & 326 \\
\hline CBA & 545 & 547,5 & 555 & 565 & 578,5 & 521,4 & 505,5 \\
\hline Coop & 500 & 510 & 510 & 510 & 530 & 550 & 560 \\
\hline Cora & $105^{*}$ & $103,5^{*}$ & $96,6^{*}$ & $86,1^{*}$ & & - & \\
\hline Csemege Match & 54,4 & 55 & $42,2^{*}$ & $41,3^{*}$ & $32,6^{*}$ & & . \\
\hline Héliker & 9 & & & & & & \\
\hline Lidl & $164,7^{*}$ & $191,2^{*}$ & $221^{*}$ & $234,6^{*}$ & $291^{*}$ & $262,9^{*}$ & $311^{*}$ \\
\hline Penny Market & $161,5^{*}$ & $161,8^{*}$ & $160,8^{*}$ & $168,7^{*}$ & $187,8^{*}$ & $196,2^{*}$ & $207,2^{*}$ \\
\hline Profi & $33^{*}$ & $28,9^{*}$ & $25^{*}$ & $28^{*}$ & $25,7^{*}$ & & \\
\hline Reál & 348 & 358 & 360 & 367 & 370 & $370^{*}$ & $379^{*}$ \\
\hline Spar & 374,2 & 397,4 & 381,3 & 389,6 & 421,2 & 453,7 & 473,7 \\
\hline Tesco & 602 & 638,4 & 665,5 & 705,2 & 709 & 704,7 & 715 \\
\hline
\end{tabular}

Forrás (Source): TRADEMAGAZIN, 2009-2015.

Megjegyzés (Notes): * Szakértők által, beszámolók alapján becsült forgalom (Turnover estimated by experts based on reports) 
A CBA mint hazai érdekeltségű lánc franchise rendszert is müködtet. A 2014. évi adatok szerint a hálózat 2289 üzletet tartalmaz, melyekkel 505,5 milliárd forintot realizált. A fenti forgalmi érték 2008-hoz képest 39,5 milliárd forinttal kevesebbet jelent, de még ezzel a csökkenéssel együtt is a lista 3. helyén szerepel, a magyar érdekeltségú láncok közül pedig a második legeredményesebb e tekintetben. A jelentős mértékü forgalom- és boltszámcsökkenés magyarázható a kényszerből kereskedelmi tevékenységet folytatók franchise-rendszerból való kilépésével és más lánchoz való átvándorlásával is. Kedvezőtlen eseményként hatott ugyanakkor valamennyi kereskedő tevékenységére a trafiktörvény és a vasárnapi boltzár egyaránt.

Franchise-tevékenységet is folytató hálózatként a Spar üzleteinek száma töretlen, visszafogott mértékü növekedést mutat 20082014 között. 419 kereskedelmi tevékenységet folytató üzlettel rendelkezett 2014-ben, mellyel 473,7 milliárd forint forgalmat tudhat magáénak, a toplista 4 . helyezettjeként.

A Reál a harmadik magyar érdekeltséggel rendelkező lánc, mely felkerült az ACNilesen által összeállított toplistára. Üzleteinek száma 2014-ben 2300 volt, mely mindössze 11 üzlettel kevesebb a 2008-as évhez képest. Forgalma 379 milliárd forint volt 2014-ben, mely 31 milliárd forinttal magasabb a bázisévhez viszonyítva. A fenti potenciál a lista 5 . helyét jelenti. ReálPONT elnevezésű franchise hálózata meghaladja a 2500 tagot.

A felsorolt három hazai tulajdonban lévő lánc együttesen a teljes magyarországi élelmiszer-kiskereskedelmi hálózat több mint felét képviseli (1. táblázat).

$\mathrm{Az}$ Auchan esetében nyolc év távlatában kevésbé dinamikus fejlődés figyelhető meg, 19 kereskedelmi helyszínnel rendelkezik (2012 óta), melyek 326 milliárd forint forgalmat hoztak a láncnak. A fenti összeg a forgalom szerinti toplistában a 6 . hely betöltését teszi lehetővé. Az Auchan 2011-ben publikálta szándékát, miszerint felvásárolja a Cora egységeit. A Match-Profi-Cora hálózat kivonulását Magyarországról 2012-ben jelentették be. A 20082011. közötti intervallumban a felsorolt cégek összforgalmukkal és üzletnyitásaikkal sem hívták fel magukra a figyelmet, így nem számított meglepő piaci döntésnek, sokkal inkább szükségszerünek (1-2. táblázat).

A Lidl 2004-ben jelent meg kereskedelmi piaci szereplőként Magyarországon. Az Aldihoz hasonlóan dinamikus fejlődés jellemzi forgalom és üzletszám tekintetében egyaránt a 2008-2014 közötti intervallumban. 163 üzletének 2014. évi forgalma 311 milliárd forint, mely a forgalom szerinti lista 7. helyét képviseli.

A kedvezőtlen gazdasági környezet ellenére napjainkban még a hálózatuk kiépítésének szakasza megy végbe, folyamatos expanzió tapasztalható, növelik boltjaik számát és a forgalmukat, s ez által élesítik a versenyhelyzetet (KOPCSAY, 2014).

A Penny Market mint nemzetközi lánc 28 üzlettel növelte portfólióját a 2008-2014 közötti intervallumban. 207,2 milliárd forint forgalmával a 8. helyen szerepel a Lidl mögött. Növekedésének értéke 45,7 milliárd forint a bázis, 2008-as évhez viszonyítva.

Az Aldi, mely 2008-ban nyitotta meg elsó üzletét Magyarországon, 2008-2014 között 100 üzletet nyitott meg a vásárlóközönség előtt. Forgalom tekintetében a lánc szintén folyamatos növekedést mutatott, így 2014-ben már 112,1 milliárd forint forgalmat ért el, ami a 9. hely megszerzéséhez volt elegendő.

Forgalmi adatokat tekintve az elemzett időszak top 3 élelmiszert és vegyi árut is értékesítő kiskereskedelmi láncok: TESCO-GLOBAL Áruházak Zrt., CO-OP és CBA.

A kereskedelmi toplista résztvevőinek erőviszonyait jelentős mértékben befolyásolták az uralkodó fogyasztói trendek. Nyilvánvaló volt, hogy megszorításokkal szükséges szembenézniük a vásárlóknak. Az élelmiszer-kiskereskedelmi szereplők a továbbiakban felsorolt trendekhez alkalmazkodtak stratégiájuk, akciós mechanizmusuk kialakítása során.

Több, a válság hatására indukálódott trend jelent meg az elmúlt években (FLATTERS és WILLMOTT, 2009).

A vásárlói trendek egyszerúsödése tapasztalható, nevezetesen recesszió alatt a fogyasztók hozzászoktak a „megszorításokhoz” és leegyszerüsítették saját igényeiket. Ennek következtében került előtérbe a mértékletesség, melynek értelmében még az a fogyasztói réteg is átgondolja kiadásait, akiknek egyébként ez nem lenne szükségszerű. „Gyors” fogyasztás 


\section{A 2009. ÉVI PÉNZÜGYI ÉS GAZDASÁGI VÁLSÁG HATÁSA AZ ÉLELMISZER-KISKERESKEDELEMRE A FOGYASZTÓI BIZALOM TÜKRÉBEN - JAVULÓ TRENDEK, ÉBREDEZŐ FOGYASZTÓI BIZALOM}

során a fogyasztók reakciókészsége növekedett, gyorsan követik az árak változását, könynyen változtatnak márkát. A „zöld” fogyasztás tendencia lassult a recesszió alatt, mert az emberek nem hajlandóak arra, hogy többet fizessenek bizonyos termékekért, amelyeket olcsóbb termékekkel is tudnak helyettesíteni. A csökkenő adakozási és jótékonysági hajlam az „etikai” fogyasztás mérséklődését eredményezte, melynek hátterében a jövőbe vetett bizalmatlanság, kiszámíthatatlanság állnak.

JANKUNÉ, STAUDER és GYÖRE (2012) az alábbi trendeket prognosztizálták:

- Választékoptimalizálás - a diszkontok előretörése, mely beigazolódott a kényelmi vásárlások és időhiányos életmód előtérbe kerülő trendje során.

- A kis boltok lehetősége - a vasárnapi kereskedelmi tilalom során új lendületet kaptak, mivel képzett családtag is végezhet kiszolgálást.

- A sajátmárkás termékek sikere - valóban új pályára lépett a kategória, valamennyi láncnál minőségi expanzió ment végbe kereskedelmi márkáik tekintetében.

- A hüségkártya-programok szerepe megnő - az élen álló TESCO, valamint a SPAR, Penny Market alkalmazza legintenzívebben. A többi lánc még kezdeti állapotot képvisel e tekintetben.

- Technológiai fejlesztésekkel elérhető költségoptimalizáció - mely elsősorban a megrendelés, készletezés, vagyonvédelem szempontjából tekinthetô jelentősnek.

A felsoroltakat egészíti ki (LEHOTA, 2001) megállapítása, mely szerint az élelmiszerek kezelésének módja is változott a racionalizáció megjelenésével, melyet az érzelmi szempontok is kiegészítenek.

A továbbiakban a vizsgált időszak alatti kereskedelmet érintő kormánypolitikai intézkedések ismertetése következik.
A 2011-ben bevezetésre került népegészségügyi termékdíj jelentős problémát okozott a kereskedők számára is. A már egyébként is éles árharc-helyzetben a fenti tényező megjelenésével újabb akadály gördült a szektorban jelenlévő valamennyi hálózat és bolttípus elé.

A beszállítók ellehetetlenítését és egyben a tisztességtelen kereskedelmi gyakorlatot is mellőzve, az új adónem rótta terheket egyaránt átvállalták a kereskedők is. Abszolút nyertesnek a lánc végén szereplő, adóval érintett termékeket vásárlók sem tekinthetők, a részben arányos teherviselés mellett sem. A rendelkezésre álló diszkrecionális jövedelem nehezen tette lehetővé például az áremeléssel (5-10\%) érintett kedvenc snack termék megszokottak szerinti vásárlási mechanizmusát.

A (népegészségügyi termékadó) NETA bevezetése mint adópolitikai lépés abból indul ki, hogy az élelmiszervásárlások esetén a döntést erôsen meghatározza az ár, s így a magasabb ár ellenösztönzőként hat (EC.EUROPA. EU, 2013). A fenti megállapítással összefüggő tény, hogy a magyar vásárlók árérzékenyek, az ACNilsen Piackutató felmérése szerint 43\%-nál dominál a termék ára vásárláskor (PIACKUTATASOK, 2011).

A Kormány 2012. október 5-én döntött az online pénztárgépek bevezetéséról, mely intézkedéssel a gazdaság tisztulását próbálják elősegíteni, és a bejelentett forgalmak növekedését várják.

2013-ban került bevezetésre a trafikrendszer, mely újabb nehézséget állított a kereskedelmi résztvevők elé. A dohánytermékek vásárlása utáni forgalom elvesztése mellett egyéb termékkategóriák forgalmának csökkenése is jelentkezett, nevezetesen az impulzus-, kasszazónában kihelyezett termékeké.

Utóbbi szabályozás ellenére a Központi Statisztikai Hivatal jelentése szerint 2014 decemberében 3\%-kal nőtt az élelmiszer-kiskereskedelem forgalmának volumene az előző év adataihoz képest (KSH, 2015). 


\subsection{A 2015. év kereskedelmi eseményei \\ - Events of the Trade in 2015}

A 2015. év kereskedelme korántsem nevezhetó „könnyített pályának”. Elég csak az alábbi kormányzati döntésekre visszatekintenünk: vasárnapi boltzár, élelmiszerlánc-felügyleti díj, illetve a kiskereskedelmi törvény 2015. január 1-jén életbe lépő módosítása, miszerint a két egymást követő évben veszteségesen múködő üzleteknek megszűnik a kereskedésre vonatkozó joga. Utóbbi tényező a TESCO 13 boltjának bezárását okozta. A vásárlási szokások a vasárnapi boltzár hatására átrendeződtek, egyértelmú volt, hogy a hét végéhez közelebb álló napok és a hétfő forgalma fog megemelkedni. Pálinkás Zsolt, a TESCO múködési ügyvezető igazgatója szerint vasárnap előtt tudatosabb vásárlást bonyolítanak vásárlóik (CSÁSZÁR, 2015).

A fentieket igazolja egyéb kereskedelmi cégek akcióinak héten belüli átütemezése is, nemzetközi láncoknál maradva például a Spar „Hétvégi szuperakciója” és „Hétindító szuperakciója”. A Lidl akciós ajánlatai csütörtöktől szerdáig tartó ajánlatokkal várja vásárlóit, a „Szuper Hétvége!” és hétfőtől szerdáig tartó ajánlata mellett. A hazai láncok akciós mechanizmusai között megtalálható például a Reál régiós tagok esetében működő „Bevásárló hétvége" c. akciója, mely heti rendszerességgel tartalmaz csütörtöktől szombatig tartó ajánlatot 15-20 termékkel.

A fentebb felsorolt akciók olyan termékösszetételt tartalmaznak, melyek hangsúlyozzák például a hétvégi teendők, szokások elvégzésének megkönnyítését vásárlóik mindennapjaiban. Így például vannak bennük vasárnapi ebédhez alapanyagok, tisztítószerek, szabadidőtöltéshez, például kiránduláshoz kínált snack ajánlat. Ezek a kereskedők részéról alkalmazkodásnak tekinthető stratégia részei, egyfajta „mankóként” értelmezendők. Nem elegendő az, hogy egy terméket megfelelő áron kínálnak a vásárlóközönségnek, az időzítés és megszólítás (!) is ugyanolyan fontossággal rendelkeznek. A technikai fejlődés eredményeként a vásárlóknak számos új lehetőség áll rendel- kezésükre az információgyűjtéshez a vásárlási helyszínként szolgáló üzletről és az abban megtalálható termékek árainak, összetevőinek megtekintésére, összehasonlítására. Az egyik lehetőség az okostelefonok használatának elterjedésében található, melyet a Stephan Grüner által megfogalmazottak is definiálnak, miszerint 2015 fogyasztója „új testrészt kapott, mégpedig az okostelefont" (BAJAI, 2015a, 9. o).

Csepeli Lajos, a CO-OP Hungary Zrt. igazgatósági elnöke szerint a magyar termékekkel kapcsolatos vásárlói tudatosság trendként hat, amely minden kereskedelmi szereplőnél dominál (ÁCS, 2015). Szintén új trendként jelent meg az élelmiszer-kereskedelem piacán az egészséges étkezés, jó közérzet trendje (HALÁSZ, 2015, 52.).

A Nielsen „Mire figyel a fogyasztó?” kutatásából kiderül, hogy csökken azon háztartások száma, melyek az élelmiszerre fordítandó költéseiken próbálnának csökkenteni. Míg 2013 III. negyedévében a megkérdezettek 70\%-a váltott olcsóbb élelmiszerre, addig ez az érték 2015 III. negyedévére 59\%-ra mérséklődött (SZÛ́CS, 2015a, 24. o.)

Érdekes vizsgálati eredménynek bizonyult az, hogy bár a kiskereskedelmi forgalom volumene mennyiségben és értékben is nőtt 2014ben, így feltételezhető, hogy a hazai kiskereskedelem kilábalt a gazdasági válságból, azonban a kutatás „Gondolja-e Ön, hogy országa jelenleg gazdasági válságban van?” kérdésére a megkérdezettek 69\%-a igennel válaszolt (SZÚCS, 2015b, 25. o.). A Nielsen fent említett vizsgálatának eredménye rávilágít arra, hogy bár a kiskereskedelmi forgalom növekedésnek indult, azonban a vásárlók tudatában még döntően jelen van válság mint tényező.

A kiélezett helyzetben, melyben versengés zajlik a fogyasztók bizalmáért és vásárlási alkalmaiért ajánlott nem elfelejteni a Nestlé elnök-vezérigazgatójának, Paul Bulcke-nak a New York-i FMCG csúcskonferencián elhangzott gondolatát, mely szerint „Nem elvárni kell a fogyasztók bizalmát, hanem kiérdemelni” (BAJAI, 2015b, 12. o.). 


\section{A 2009. ÉVI PÉNZÜGYI ÉS GAZDASÁGI VÁLSÁG HATÁSA AZ ÉLELMISZER-KISKERESKEDELEMRE A FOGYASZTÓI BIZALOM TÜKRÉBEN - JAVULÓ TRENDEK, ÉBREDEZÓ FOGYASZTÓI BIZALOM}

\section{4. ÖSSZEgZÉS - SUMMARY}

$\mathrm{Az}$ élelmiszer-kiskereskedelem volumene 2014-ig mennyiségben aggasztó mértékben csökkent, míg értékben folyamatos növekedés volt tapasztalható. A felhasznált Gfk és Nielsen adatok alapján látható, hogy az élelmiszer-kereskedelemben tevékenységet folytató vállalatok forgalmában, üzletszám-alakulásában, illetve forgalmi részesedésük változásaiban is megnyilvánulnak a válság által kialakult új szokások.

A növekvő Fogyasztói Bizalom Index és részindex adatok elemzése során kiderült, hogy mélypontként a 2009-es év tekinthető. A Match-Profi-Cora hálózat kivonulása 2012-ben ment végbe, egyértelmúen a válság hatására hozott piaci lépésként. A 2013-as év FBI értékei alapot nyújtottak a 2014-es év pozitív változásaihoz. További kereskedelmi szereplő nem hagyta el a piacot 2008-2014 között. Forgalmát tekintve vezető helyen állt a TESCO, melyet a 2014. évi adatok alapján a CO-OP és a CBA követ a sorban. A 2015. évi komplex Fogyasztói Bizalom Index adatok kedvezó irányt mutattak, habár az ACNielsen Piackutató Shopper Trends című felméréséből az derült ki, hogy a hazai vásárlók még mindig úgy érzik válságban van a gazdaság. A JANKUNÉ, STAUDER és GYÖRE (2012), valamint RAMPELL (2009) által prognosztizált trendek többsége reálisnak bizonyult, így például a kényelmi boltok szerepének növekedése vagy a hűségprogramok növekvő megjelenése. Nem várt trend az egészséges termékek fogyasztásával járó jó közérzet trendje, a magyar termékek vásárlásának trendje és a technológiai fejlődés nyújtotta trend.

Az időközben megjelenő új feltételek, szabályozások ugyancsak akadályt gördítettek a kereskedelmi szereplők elé (is). Ezeknek meg kellett felelni, ugyanakkor kitörési alternatívát is keresni kellett. A vasárnapi kereskedés tilalma szolgál erre leginkább példaként. Nem volt kérdés, hogy a vásárlóknak időre lesz szükségük ahhoz, hogy elfogadják az új szabályozást, erre azonban hamar új magatartásformát hoztak létre. Élelmiszerköltéseiket korábbi időpontra hozták. Erre a trendre alakított ki akciós struktúrát a Lidl, Spar és a Reál is.

A 2016-os év kilátásai bizakodásra adnak okot. Egyrészt az online kasszarendszer a kereskedelem „kifehérítését” segíti elő, másrészt a személyi jövedelemadó kulcsa 16\%-ról 15\%ra mérséklődött, így a többletköltés realizálódhat az FMCG vásárlások során is.

\section{IRODALOMJEGYZÉK - REFERENCES}

Ács D.: Tízéves születésnapját ünnepelte a Coop Rally. In: Élelmiszer Szaklap. 2015. 23 (10) 23.

Bajai E.: FMCG globális csúcskonferencia, New York-i riport 2. rész. In: Élelmiszer Szaklap. 2015a. 23 (9) 9.

Bajai E.: FMCG globális csúcskonferencia, New York-i riport 2. rész. In: Élelmiszer Szaklap. 2015b. 23 (9) 12.

Császár L.: „Nincs vesztes helyzet”. In: Élelmiszer Szaklap. 2015. 23 (9) 6.

EC.EUROPA.EU: In: Evaluation of the Implementation of the Strategy for Europe on Nutrition, Overweight and Obesity related health issues. 2013. URL: http:// ec.europa.eu/health/nutrition_physical_ activity/docs/pheiac_nutrition_strategy_ evaluation_en.pdf(Letöltés dátuma: 2016. jan. 20.)

Flatters, P. - Willmott, M.: Understanding the Post-recession Consumer. In: Harvard Business Review. 2009. 87 (7-8) 106-112.

\section{GFK HUNGÁRIA, KOMPLEX FOGYASZTÓI BIZALOM INDEX, 2008-2015.}

2008. évi adatok: URL: http://www. marketinginfo.hu/tanulmanyok/essay. php?id=2109 (Letöltés dátuma: 2015. dec. 03.)

2009. évi adatok: URL: http://www.elelmiszer. hu/cikk/tovabbra_sem_nott_a_vasarloi_ hajlandosag (Letöltés dátuma: 2015. dec. 03.)

2010-11-12. évi adatok: URL: http://mfor.hu/ cikkek/makro/GfK__enyhen_javult_a_ fogyasztoi_hangulat.html (Letöltés dátuma: 2015. dec. 03.)

2013-14-15. évi adatok: URL: http://www. elelmiszer.hu/gazdasag/cikk/gfk_2015_ masodik_negyedeveben_javultak_a fogyasztoi_varakozasok (Letöltés dátuma: 2015. dec. 03.) 
Halász G.: Nagy boltok magas piaci részesedéssel. In: Élelmiszer Szaklap. 2015. 23 (10) 52.

Jankuné K. Gy. - Stauder M. - Györe D.: $\quad \mathrm{Az} \quad$ élelmiszer-kiskereskedelem termelékenysége és jövedelmezősége. Agrárgazdasági Kutatóintézet, Budapest, 2012.

Kopcsay L.: Az élelmiszer kiskereskedelmi hálózatok megújuló stratégiái Magyarországon, 2014-ben. „Marketing megújulás" Marketing Oktatók Klubja 20. Konferenciája. In: „Marketing megújulás” Marketing Oktatók Klubja 20. Konferenciája előadásai. Szeged, 2014. aug. 28-29.

KSH, 2011a: Jelentés a kiskereskedelem 2008-2010. évi teljesítményérôl. URL: http://www.ksh.hu/docs/hun/xftp/ idoszaki/pdf/jelkisker1o.pdf (Letöltés dátuma: 2012. ápr. 21.)

KSH, 2011b: Jelentés a kiskereskedelem 2008-2010. évi teljesítményéről. URL: http://www.ksh.hu/docs/hun/xftp/ idoszaki/pdf/jelkisker1o.pdf (Letöltés dátuma: 2012. ápr. 21.)

KSH, 2015: Kiskereskedelem, 2014. december (második becslés). URL: http:// www.ksh.hu/docs/hun/xftp/gyor/kis/ kis1412.pdf (Letöltés dátuma: 2015. szept. 20.)

Lehota J.: Az élelmiszer - vásárlói és fogyasztói magatartás rendszere. In: Élelmiszer-gazdasági marketing. (Szerk.: Lehota J.). Műszaki Könyvkiadó Kft., Budapest, 2001. 19-26.

Pearson, C. M. - Clair, J. A.: Reframing Crisis Management. In: Academy of Management Review. 1998. 23 (1) 59-76.

Piackutatasok: Nielsen - Élelmiszervásárlás 47 százaléknál az ár-érték-arány a legfontosabb, 2011. 08.12. URL: http:// www.piackutatasok.hu/2011/o8/nielsenelelmiszer-vasarlas-47.html (Letöltés dátuma: 2015. nov. 05.)

Rampell, C.: Outsourced Chores Come Back Home. In: The New York Times. Business Section. 16. Jan. 2009.
Rekettye G. - Törőcsik M. - Hetesi E.: A magyar fogyasztó jellemzőinek változásai. In: Bevezetés a marketingbe. (Szerk.: Törőcsik M.). Akadémiai Kiadó Zrt., Budapest, 2015. 97-99.

Szúcs V. Á.: Mire figyel a fogyasztó? In: Élelmiszer Szaklap. 2015a. 23 (9) 24.

Szúcs V. Á.: Mire figyel a fogyasztó? In: Élelmiszer Szaklap. 2015b. 23 (10) 25.

Tiner T.: A fogyasztás globális trendjei. In: A válság hatása a kiskereskedelemre. (Szerk.: Sikos T. T. - Beluszky P. - Hajdú Z. - Káposzta J. -Tiner T.). Szent István Egyetemi Kiadó, Gödöllő, 2013. 45-58.

Tisza A.: Hosszú idő után a háztartások újra növelték napi fogyasztási cikk költéseiket. 2015. ápr. 14. URL: https://www.gfk.com/ fileadmin/user_upload/dyna_content_ import/2015-09-01_press_releases/ data/hu/Documents/20150414_GfK_ Kiskereskedelmi\%2otrendek.pdf (Letöltés dátuma: 2015. ápr. 18.)

Tóth Á.: Bolttípusok előnyei, ahogy a vásárlók látják. 2010. jún. 24. URL: http://www. elelmiszer.hu/fmcg_szakmai_hirek/ cikk/bolttipusok_elonyei__ahogy_a_ vasarlok_latjak (Letöltés dátuma: 2015. szept. 23.)

Törőcsik M.: A vásárlás helyének megválasztása. In: Vásárlói magatartás. (Szerk.: Törőcsik M.). Akadémiai Kiadó Zrt, Budapest, 2007. 190-196.

Trademagazin, 2009: Nielsen Toplista Üzletláncok rangsora 2008-ban. URL: http: / / www.trademagazin.hu/wpcontent/uploads/2010/o8/toplista-2008. pdf (Letöltés dátuma: 2015. dec. 18.)

Trademagazin, 2010: Nielsen Toplista Üzletláncok rangsora 2009-ben. URL: http://www.trademagazin.hu/wpcontent/uploads/2010/08/toplista-2009. pdf (Letöltés dátuma: 2015. dec. 18.)

Trademagazin, 2011: Nielsen Toplista Üzletláncok rangsora 2010-ben. URL: http://www.trademagazin.hu/wpcontent/uploads/2011/04/Toplista_2011. pdf (Letöltés dátuma: 2015. dec. 18.) 
Trademagazin, 2012: Nielsen Toplista 2011. URL: http://www.trademagazin.hu/wpcontent/uploads/2012/04/toplista2011. pdf (Letöltés dátuma: 2015. dec. 18.)

Trademagazin, 2013: Nielsen Toplista 2012. URL: http://www.trademagazin.hu/wpcontent/uploads/2013/o6/toplista_2012. pdf (Letöltés dátuma: 2015. dec. 18.)
Trademagazin, 2014: Trade Magazin - Kiskereskedelmi Toplista 2013. URL: http://www.trademagazin. hu/wp-content/uploads/2014/o6/ Toplista-2013_final_20140601.pdf (Letöltés dátuma: 2015. dec. 18.)

Trademagazin, 2015: Trade Magazin Kiskereskedelmi Toplista 2014. URL: http://www.trademagazin.hu/wpcontent/uploads/2015/o6/kereskedelmi_ toplista_2014.pdf (Letöltés dátuma: 2015. dec. 18.)

\section{JEGYZETEK * NOTES}


JEGYZETEK $\nRightarrow$ NOTES 